\title{
Proportion of exported non-oil and gas commodities for manufacturing industries, case study in the City of Cilegon
}

\author{
Julia Thio, Fahma Husnalawati, Fatma Kusuma Porodani, Afifudin, Anggun Nurzahwa Haris, Jaa'ana Nurur Riza, \\ Ridho Dayan Bagus, and Ratih Fitria Putri*
}

Department of Enviornmental Geography, Faculty of Geography, Universitas Gadjah Mada, Indonesia

\begin{abstract}
Export activities are important to the economic growth of the country, especially for developing countries. The city of Cilegon in Banten Province is the main city for the manufacturing industry in Indonesia, mainly for its iron and steel products. This study aims to determine the proportion of exported goods for the manufacturing industry in the City of Cilegon and make suggestions for further development. Data used are BPS publications 2016-2020, LQ is calculated to know the basis of the economic sector in the city. According to the calculation, the manufacturing industry in the City of Cilegon shares $59.70 \%$, the highest among other regions. Commodities that dominated the export trade are footwear, plastic products, iron and steel products, while the US, China, and Japan were the countries that had the highest FOB. To escalate export performance and intensity, it is necessary to consider market and competitors' networks, improvement of education and transport infrastructure, along with environmental and social-cultural impacts.
\end{abstract}

\section{Introduction}

Each country has different kinds of resources (either its natural and human resources). Therefore trade between countries cannot be avoided. Apart from making a profit, trade between countries (international trade) is meant to fulfil the citizens' needs. The difference in the quantity and quality of products from a country leads them to trade with other countries [1]. Globalization and open trade have helped the world economy to grow, especially for the origin country. According to Kalafsky and Gravers [2], exports have long been considered an important factor to enhance economic development by policymakers (particularly export-oriented manufacturing). Also, Brightnell [3] said, "By distributing commodities in surplus to places where they are in deficit, a new form of global equality is imagined here through transoceanic shipping and borderless flow of luxury commodities".

Export activities are meaningful for developing countries, because of their contribution through positive externalities, gain benefits from foreign buyers and creating a competitive market [1]. The higher the revenue from the export-base sector, the higher the profit and its economic growth. Therefore, it can be said that exports are determining the rate of regional economic growth. Exporting commodities requires knowledge about foreign markets and fixed costs for business [4]. Previous research shows [4] that exporting firms would locate near others and form agglomeration to share transport infrastructure, knowledge of foreign markets, marketing, exhibition, banking, and exporting credit insurance. In the context of Indonesia, it can be seen in the City of Cilegon.

The city of Cilegon in Banten Province is the main city for the manufacturing industry in Indonesia. The manufacturing industry, especially the chemical and steel sector, in Cilegon gives a big portion for its GRPD (Gross Regional Domestic Product). Data from BPS (Badan Pusat Statistik/Central Bureau of Statistics Republic of Indonesia) showed the manufacturing industries had $57 \%$ of the GRDP proportion in the City of Cilegon [5] [6], which is the highest compared to other sectors and regions in Banten Province. According to district boundary by government and high demand places to invest, there are several industrial districts: JIIPE (Gresik, East Java), Sentul (Bogor, West Java), Tugu Wijaya (Semarang, Central Java), Kertajati International Industrial Estate Majalengka (West Java), Cilegon (City of Cilegon, Banten), etc. [7].

The Ministry of Industry [8] has been supporting the manufacturing industry in the City of Cilegon, which is infrastructure development to promote national and international investments. Furthermore, the increasing infrastructure to support the manufacturing activities could intensify the quality of the goods and could compete with national and international markets.

Even though Cilegon has many big manufacturing industries, the productions are unable to meet all the community needs. Indonesia, especially Banten Province, has high rates of imported goods such as live animals, foodstuffs, and oil [9] [10] [11] [12] [13]. Export and import activities are very reasonable to do, in addition to meeting the needs of a country that has

\footnotetext{
*Corresponding author: ratihfitria.putri@ugm.ac.id
} 
problems with high demand but less supply and to increase the country's foreign exchange. It is also carried out to establish trade cooperation with other countries so that the local trade market can be known by many countries.

Therefore, this study aims to determine the proportion of exported goods for the manufacturing industry. We are also going to give suggestions for further development. Before that, we are going to calculate the LQ (Location Quotient) to prove the basis of the economic sector in the study area.

The city of Cilegon is used as a study area because this city is known as an Industrial City or the City of Steel, where the industrial area has been integrated and its infrastructure constructed (Fig. 1). The City of Cilegon itself is used by the government as an example of an industrial district outside Java [8].

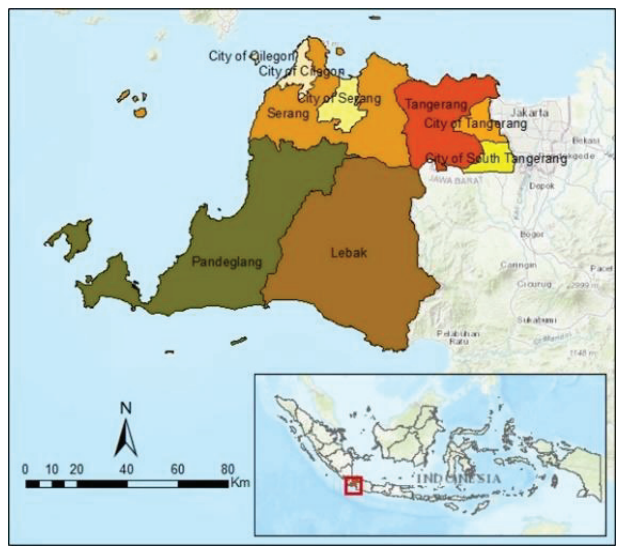

Fig. 1. Banten Province of administration boundary Source: Data processing (2021)

The city of Cilegon has various kinds of infrastructure supporting industry activities in Banten and it is close to trading distribution roads, including Soekarno-Hatta International Airport, Merak Port, Jakarta-Merak Highway, Jakarta-Rangkasbitung-Merak Railway Network, and the Port of Bojonegara [8]. Those points add up the value of the city, which give proof of the strategic location for domestic and foreign investment. One of the industrial successes in the City of Cilegon is a Joint Venture investment between PT. Krakatau Steel with PT. Pohang Steel Corporation from Korea. This success triggered other companies to participate in expanding their business such as PT. Nippon Shokubai Indonesia, PT. Candra Asri, and PT. Asahimas Petrochemical Indonesia.

This research is limited to the discussion of exported commodities by considering the market price of goods and country of destination. The discussion will not consider the natural and social environmental impacts of manufacturing activities.

There are four sections in this paper. The first section will explain the research background and the aims. In section two, the data and methods we use to analyze are explained, while in section three there are tables from data collection and calculation. The last section (4) is the conclusion and suggestions.

\section{Data and method}

\subsection{Data}

Secondary data for this research is obtained from BPS and other relevant literature. There are two types of data to analyze the economy of the manufacturing industry: Gross Regional Domestic Product (GRDP) per business field and GRDP from the City of Cilegon, also the publication of export goods from the year 2015-2019. GRDP is needed to calculate LQ (Location Quotient) to determine the base of the economic sector in the City of Cilegon. To analyze exported commodities, the data used are export commodities according to its raw material through Harmonized System Code or HS 2 digits 2012 version (simpler compared to SITC system), and the countries which have the trade. Furthermore, the data is processed using descriptive techniques in the form of visual graphs and tables, followed by an analysis of each topic based on related literature.

\subsection{Method}

GRDP in 2015-2019 based on constant market prices at city and province-level are used to know the Location Quotient (LQ) number. LQ is used to determine the level of specialization of the basic or the prime sector by comparing it with other industrial sectors on the regional economic scale [14]. In general, LQ is formulated as follows [15]: variable vi resembles sector $i$ GRDP in a region (district), $v t$ - total GRDP in the region (district), $V i$ - GRDP from sector $i$ in higher administration level (province), and $V t$-total GRDP in higher administration level (province). If the $\mathrm{LQ}<1$, it indicates that sector $i$ is not the region basis (non-base), while LQ $>1$, sector $i$ is the base economy for the region.

$$
L Q=\frac{v i}{v t} / \frac{v i}{v t} \text { or } L Q=\frac{v i}{v i} / \frac{v t}{v t}
$$

\section{Results and discussion}

The manufacturing industry is the basis of the economic sector in the City of Cilegon (Table 1). The processing industry in Banten contributes the highest GDP compared to other sectors. With the basis of the processing industry in the City of Cilegon and decent ports, it supports the existence of the City of Cilegon as an investment destination. The City of Cilegon has an economic base on three sectors, there are manufacturing; electricity and gas; water supply, sewerage, waste management, and remediation activities, scored 1.76; 3.12; and 2.66 respectively (Table 1). Electricity and gas sector along with water supply, sewerage, waste management and remediation activities sector indeed have had high LQ value, as all the industries need energy and water.

Table 2 describes the percentage of the GRDP manufacturing share in total compared with the province GRDP. Manufacturing in the City of Cilegon contributes $59.70 \%$ among other regions. The existence 
of PT. Krakatau Industrial Estate Cilegon (KIEC) which processes steel is one of the factors that the manufacturing industry is the base economy in the City of Cilegon. The Indonesia government itself hopes that Banten, especially the CIty of Cilegon, contribution to international trade could improve the local economy growth and its population welfare, as well as other regions in Indonesia too [12].

Export rates are dependent on global economic conditions. The slowdown in the economy can lead to an economic slowdown which affects the export development of Banten and also Indonesia in general. Vice versa, if the global economy experiences faster growth, it will drive world demand and then affect the increase in demand for Banten's export goods. Exports in Banten in 2015-2019 experienced a fairly good condition, although in 2019 the FOB value decreased due to the global crisis [12].

Table 1. LQ calculation the City of Cilegon in 2019

\begin{tabular}{|c|c|c|}
\hline Sector & LQ & Category \\
\hline \multicolumn{3}{|l|}{ City of Cilegon } \\
\hline A. Agriculture, Forestry and Fishery & 0.04 & Non-Basis \\
\hline B. Mining and Quarrying & 0.07 & Non-Basis \\
\hline C. Manufacturing & 1.76 & Basis \\
\hline D. Electricity and Gas & 3.12 & Basis \\
\hline $\begin{array}{l}\text { E. Water Supply, Sewerage, Waste } \\
\text { Management, and Remediation } \\
\text { Activities }\end{array}$ & 2.66 & Basis \\
\hline F. Information and Communication & 0.19 & Non-Basis \\
\hline
\end{tabular}

Source: BPS (2020)

Table 2. GRDP sector manufacturing in 2019

\begin{tabular}{|l|c|c|c|}
\hline \multicolumn{1}{|c|}{ Region } & $\begin{array}{c}\text { GRDP per } \\
\text { sector (Rp) }\end{array}$ & $\begin{array}{c}\text { Total GRDP } \\
\text { (Rp) }\end{array}$ & $\begin{array}{c}\text { Percentage } \\
\text { (\%) }\end{array}$ \\
\hline City of Cilegon & $44,411,694.70$ & $74,385,223.50$ & 59.70 \\
\hline $\begin{array}{l}\text { Pandeglang } \\
\text { Regency }\end{array}$ & $1,293,388.7$ & $19,895,912$ & 6.5 \\
\hline Lebak Regency & $2,099,454.91$ & $20,908,728.37$ & 10.04 \\
\hline $\begin{array}{l}\text { Tangernag } \\
\text { Regency }\end{array}$ & $35,904,811.20$ & $97,142,198.47$ & 36.96 \\
\hline Serang Regency & $26,890.41$ & $54,404.47$ & 49.43 \\
\hline $\begin{array}{l}\text { City of } \\
\text { Tangerang }\end{array}$ & $39,599,102.87$ & $110,592,776.31$ & $35.80 \%$ \\
\hline City of Serang & $1,065,416.90$ & $22,813,096.36$ & 4.67 \\
\hline $\begin{array}{l}\text { City of South } \\
\text { Tangerang }\end{array}$ & $5,021,653.81$ & $60,145,115.32$ & 8.33 \\
\hline $\begin{array}{l}\text { Banten } \\
\text { Province }\end{array}$ & $\mathbf{1 5 4 , 8 4 9 , 8 5 5 . 9 8}$ & $\mathbf{4 5 6 , 7 4 0 , 8 2 7 . 8 5}$ & $\mathbf{3 3 . 9 0}$ \\
\hline
\end{tabular}

Source: BPS (2020)

Non-oil and gas processed commodities have been dominating the city trade. Over the last 5 years since 2015 (Fig. 2), there were 10 top commodities that dominated the trade. The first rank was for footwear, followed by plastic products, and iron and steel. From Fig. 2, it is clear that for 5 years, the FOB had increased and decreased. In 2015 until 2018, there was positive economic growth in the Province of Banten. Nevertheless, in 2019 the revenue was slightly decreased because of the global crisis [12]. Fig. 3 shows the detailed proportion of exported commodities in the Province of Banten in 2019.

The City of Cilegon is known for its steel company and production, but its proportion was not much compared to other commodities. This anomaly could be due to the source of data. The exported and imported data are only available at the province level. Iron and steel commodities are considered as top 10 commodities since 2014 (US\$ 505,77 million). In 2013 and the previous years, iron and steel commodities had FOB value less than US\$ 100 million (in 2013, the value was US $\$ 85,45$ million) [17]. The spike from 2013 to 2014 leads the commodities to reach the top 5 for the next few years. It happened as PT Krakatau Steel started to collaborate with POSCO Korea in December 2013 and was named as PT Krakatau POSCO. The new collaboration used the best technologies, with their capacity to produce 3 million tons of iron and steel plates per year [18]. It technically escalated productivity.

Based on Fig. 4, the United States, China and Japan have become non-oil and gas export destinations with FOB (Free on Board) value of more than US\$ 700 million since 2015. These three countries have become the main destinations for non-oil and gas exports compared with other countries (less than US\$ 500 million). The value of Banten Province's non-oil exports have always increased since 2015 - 2018, but there is a slight downward in 2019. The highest non-oil export is the United States with a FOB value exceeding US\$ 1000 million.

The United States, China, and Japan are Indonesia's trading partner countries, which are considered to have had a strong economic cooperation relationship and have been the destination of Indonesia's export market for a long time [16]. It is also said that Japan has been the main export partner to Indonesia since the late 1990s and around the 2010s, China had started becoming one of the main export destinations [19]. The other countries are mainly from Asia: Philippines, South Korea, Thailand, Vietnam, Malaysia, India, Singapore; also other countries Germany and Australia. Asias' countries have dominated the destination of free trade from Indonesia since the distance is close and have politicaleconomic engagement.

The United States, China, and Japan are also part of international agreements with Indonesia. AFTA (ASEAN Free Trade Area) had economic partnerships with China, Australia, Japan, India, South Korea, and the United States. The two agreements are: the ChinaASEAN Free Trade Agreement (CAFTA) and the General System of Preferences (GSP). The agreements allow easier procedure, regulation, access to markets, and transfer of information between countries. It helps the exporter country to reduce the cost for the trade. 
There are many possibilities that the same category of products is being exported and imported (two-way intra-industry exchange), but with different valueadded. In Indonesia, the value-added for the products is less than 20\%, which is lower than China, Thailand, and Malaysia [20] due to a lack of advanced technology. Most of the export manufacturing in Indonesia is resource-based and low technology-based products.

Looking back at the crisis in 2019 and how the investment in manufacturing has weakened are likely to put Indonesia's economy at risk [21]. It could lead to decreasing productivity and diminishing the amount of labour. Employment in the manufacturing sector (and other services) has accelerated poverty alleviation [20]. And unfortunately, as the fourth populous country, Indonesia contributed only $0.84 \%$ of the world exports $[22]$.

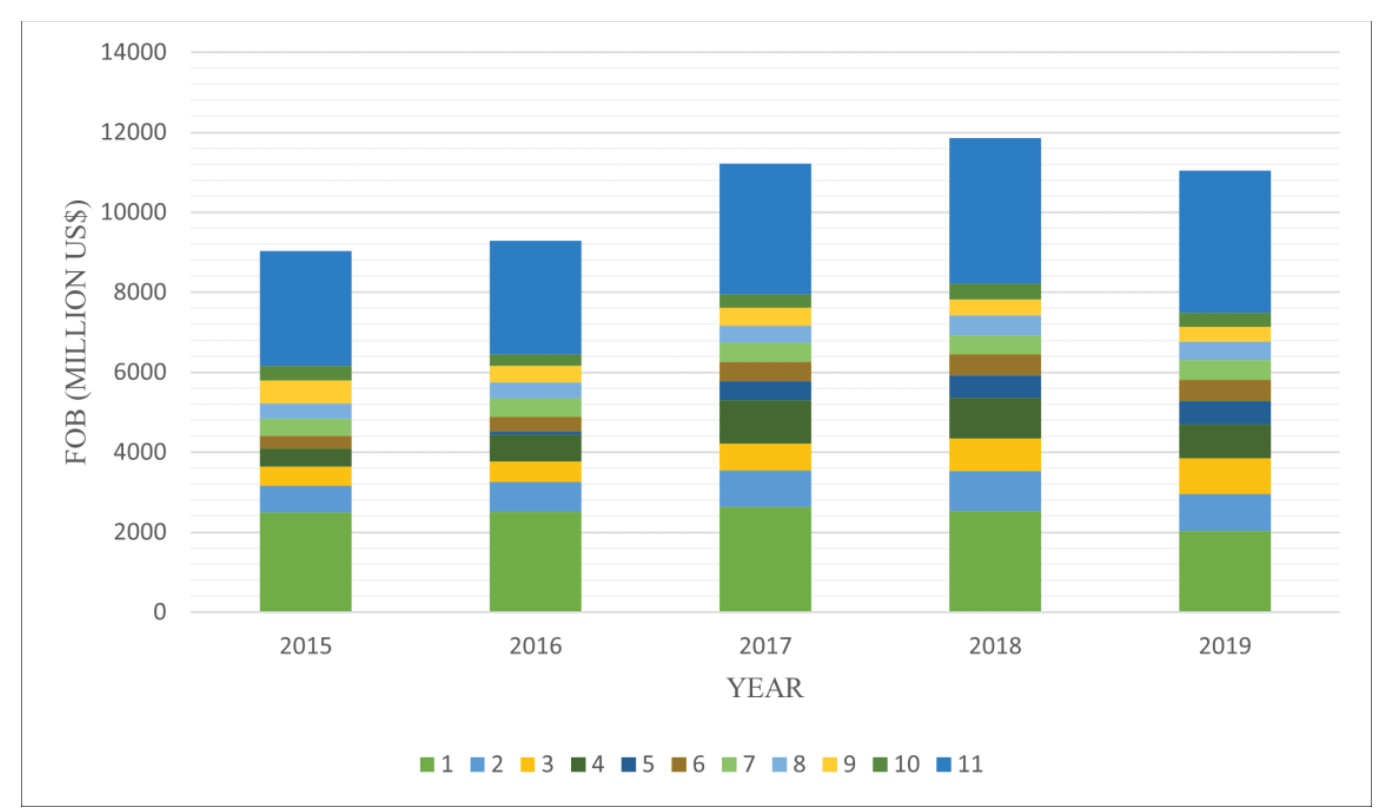

Fig. 2 FOB of exported commodities in Banten Province HS 2 digits Code (2015-2019) Source: BPS (2016-2020)

Notes: (1) Footwear, (2) Plastic products, (3) Iron and steel, (4) Organic chemicals, (5) Various Processed foods, (6) Machinery/aircrasft mechanics, (7) Rubber products, (8) Electrical machinery and equipment, (9) Copper, (10) Paper and cardboard, (11) others

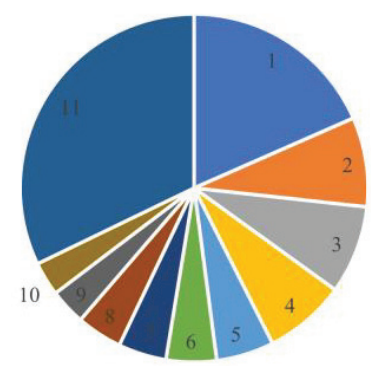

Fig. 3 Exported commodities in Banten Province HS 2 digits code (2019) Source: BPS (2020)

Notes: (1) Footwear, (2) Plastic products, (3) Iron and steel, (4) Organic chemicals, (5) Various Processed foods, (6) Machinery/aircrasft mechanics, (7) Rubber products, (8) Electrical machinery and equipment, (9) Copper, (10) Paper and cardboard, (11) others
Improving the export performance and intensity is needed to keep the development growth. However, the nufacturing impacts on environmental and sociodoes not mention it). The other things that need to be nsidered to enhance the export performance and . al. [19] also mentioned that in export performance. Other than increasing export performance and intensity, escalating the product's quality is also needed. 


\section{Conclusion}

Export activities in the Province of Banten are dominated by non-oil and gas commodities for industrial products, no exception for the City of Cilegon. The commodities which gave the biggest share of FOB in 2019 were footwear, plastic products, and iron and steel products. Iron and steel products have been included in the top 10 exported commodities since 2014 due to the company escalating productivity. The United States, China, and Japan are the top 3 countries that had high FOB. The high FOB for those three countries was influenced by bilateral or regional policies in international trade that facilitate and allow easier procedure, regulation, access to markets, and transfer of information between countries.

Further research regarding the improvement of footwear, organic chemical, and plastic products are needed, especially for its environmental impacts. Also, the Province of Banten itself has footwear, textile commodities which share high FOB for more than 10 years. Study and other development should be conducted to ensure the province's economic growth for its potential commodities.

Studies regarding the export macroeconomy in Indonesia is also crucial. There are limited updated studies for export commodities in terms of macroeconomy and geography. Because such studies are necessary for export planning, policy, and the development of exported products themselves.

\section{References}

1. A. H. Yahya, N. Mohd, S. Syahnur, Aceh Int. J. Soc. Sci, 4: 56-67 (2015)

2. R. V Kalafsky, W. Graves, R. V Kalafsky, W. Graves, Southeast Geogr., 56, 2 (2016)

3. T. Birtchnell, Area, 45, 4:436-442(2013)

4. C. He, Q. Guo, X. Ye, GeoJournal, 81, 6: 947-964 (2016)

5. BPS, Kota Cilegon Dalam Angka 2016 (2017)

6. BPS, Kota Cilegon Dalam Angka 2020 (2021)

7. Kementerian Perindustrian, Links Kawasan Industri (2016)

8. Kementerian Perindustrian, Kawasan Industri Banten Jadi Proyek Percontohan di Luar Jawa (2016)

9. BPS, Ekspor dan Impor Provinsi Banten 2016 (2017)

10. BPS, Ekspor dan Impor Provinsi Banten 2017 (2018)

11. BPS, Ekspor dan Impor Provinsi Banten 2018 (2019)

12. BPS, Ekspor dan Impor Provinsi Banten 2019 (2020)

13. BPS, Ekspor dan Impor Provinsi Banten 2020 (2021)
14. Emilia, Imelia, Modul Ekonomi Regional. Jambi: Fakultas Ekonomi Univ. Jambi (2006)

15. Kadiriah, Ekonomi Perencanaan. Jakarta: LPFE Universitas Indonesia (1985)

16. Sabaruddin, J. Ilm. Hub. Int., 12, 2: 205-219 (2017). DOI: 10.26593/jihi.v12i2.2654.205-219.

17. BPS, Ekspor dan Impor Provinsi Banten 2014 (2015)

18. KrakatauPOSCO, www.krakatauposco.co.id/ (2019)

19. A. Rodríguez-Pose, V. Tselios, D. Winkler, T. Farole, World Dev., 44, 269868: 225-240 (2013). DOI: 10.1016/j.worlddev.2012.12.002.

20. F. Kimura, L. Chen, Bulletin Indonesian Economic Study, 54, 2: 165-192 (2018). DOI: 10.1080/00074918.2018.1505412.

21. P. J. Burke, M. D. Siyaranamual, Bulletin Indonesian Economic Study, 55, 3: 269-293 (2019). DOI: 10.1080/00074918.2019.1690410.

22. T. Y. Wicaksono and C. Mangunsong, Bulletin Indonesian Economic Study, 56, 4: 1-41 (2021). DOI: $10.1080 / 00074918.2020 .1866745$.

23. J. A. Belso-Martínez, Eur. Plan. Stud., 14, 6: 791810 (2006). DOI: 10.1080/09654310500496115. 